\title{
PENGARUH KUALITAS PELAYANAN, BIAYA PENDIDIKAN, DAN KELOMPOK REFERENSI TERHADAP KEPUTUSAN MAHASISWA PENDIDIKAN EKONOMI MEMILIH PADA PROGRAM STUDI PENDIDIKAN EKONOMI
}

\author{
Supardin \\ e-mail: Supardin@gmail.com \\ Ninik Indawati \\ e-mail:ninik@unikama.ac.id \\ Walipah \\ e-mail:walipah@unikama.ac.id
}

(Program Studi Pendidikan Ekonomi, Fakultas Ekonomika dan Bisnis, Universitas Kanjuruhan, Malang)

\begin{abstract}
This research is a quantitative approach. With explanatory type research. The study population was students of economic education class of 2015-2018 Faculty of Economics and Business, University of Kanjruhan Malang. Sampling using proportional random sampling technique with a sample of 62 students. Data collection techniques using questionnaires and documentation. Analysis of the data used is multiple linear analysis. The results showed that: (1) the quality of service, the cost of education, and the reference group jointly had a positive effect on student decisions, with an F value of 14,623 and a significance level of 0,000. (2) the quality of service has a positive effect on student decisions, with a t value of 6,039, and a significance level of 0,000. (3) the cost of education has an effect on student decisions, with a tcount of -2.093 and a significance level of 0.041. (4) the reference group has a positive effect on student decisions, with a $t$ value of 2.172 and a significance level of 0.034 . $R 2$ Test The value of the determinant coefficient ( $R$ Square) shows $R 2$ of $43.1 \%$, while the remaining $56.9 \%$ is affected by other factors outside the variables of this study
\end{abstract}

Keywords : service quality, costs, references, student decisions

\begin{abstract}
Abstrak: Penelitian ini merupakan penelitian dengan pendekatan kuantatif. Dengan jenis explanatory research. Populasi penelitian adalah mahasiswa pendidikan ekonomi angkatan 2015-2018 Fakultas Ekonomika dan Bisnis Universitas Kanjruhan Malang. Pengambilan sampel mengunakan teknik Proporsional random sampling dengan jumlah sampel 62 mahasiswa. Tenik pengumpulan data dengan mengunakan angket dan dokumentasi. Analisis data yang digunakan adalah analisis linier berganda. Hasil penelitian menunjukkan bahwa: (1) kualitas pelayanan, biaya pendidikan, dan kelompok referensi secara bersama-sama berpengaruh secara positif terhadap keputusan mahasiswa, dengan nilai F sebesar 14.623 dan taraf signifikansi 0,000. (2) kualitas pelayanan berpengaruh positif terhadap keputusan mahasiswa, dengan nilai t hitung sebesar 6.039, dan taraf signifikansi sebesar 0,000. (3) biaya pendidikan berpengaruh tehadap keputusan mahasiswa, dengan nilai thitung sebesar -2.093 dan taraf signifikansi sebesar 0,041. (4) kelompok referensi berpengaruh secara positif terhadap keputusan mahasiswa, dengan nilai thitung sebesar 2.172 dan taraf signifikansi sebesar 0,034 . Uji R2 Nilai koefisien determinan ( $R$ Square) menunjukan $R 2$ sebesar 43,1\%, sedangkan sisanya 56,9\% di pengaruh oleh faktor lain diluar variabel penelitian ini.
\end{abstract}

Kata Kunci : : kualitas pelayanan, biaya, referensi, keputusan mahasiswa 


\section{PENDAHULUAN}

Pengertian pendidikan tercantum dalam UU RI No. 20 tahun 2003 tentang Sistem Pendidikan Nasional, diartikan sebagai usaha sadar dan terencana untuk mewujudkan suasana belajar dan proses pembelajaran agar peserta didik secara aktif mengembangkan potensi dirinya untuk mendapatkan kekuatan spiritual keagamaan, pengendalian diri, kepribadian, kecerdasan, akhlak mulia, dan keterampilan yang diperlukan dirinya, masyarakat, bangsa serta negara. Setiap orang mempunyai hak yang sama dalam mengikuti dan mendapatkan kesempatan belajar atau pendidikan sebagaimana telah diamanatkan oleh Undang-Undang Dasar 1945.

Perguruan tinggi merupakan jenjang pendidikan setelah jenjang pendidikan menegah (SMA/MA, SMK). Dalam UU No.12 Tahun 2012 tentang Pendidikan Tinggi pada pasal 1 ayat 1 disebutkan yakni: Pendidikan menengah adalah jenjang pendidikan sebelum pendidikan tinggi. Pendidikan tinggi berupa diploma, sarjana, magister, doktor, dan profesi, dan program spesialis, yang diselenggarakan oleh perguruan tinggi berdasarkan kebudayaan bangsa Indonesia. Perguruan Tinggi (PT) di Indonesia terbagi menjadi 2 yaitu Perguruan Tinggi Negeri (PTN) dan Perguruan Tinggi Swasta (PTS).Universitas Kanjuruhan Malang merupakan perguruan tinggi swasta jelmaan dari Institusi Keguruan dan Ilmu Pendidikan (IKIP) yang berada dikota Malang. Universitas Kanjuruhan Malang memberikan perhatian besar pada bidang pendidikan. Dari 18 program studi (https://unikama.ac.id), 11 program studi di antaranya merupakan program studi FIP (Fakultas Ilmu Pendidikan) dengan gelar sarjana pendidikan (S.Pd) bagi lulusannya. Bukan hanya pada jenjang sarjana, Universitas Kanjuruhan Malang juga memgelola beberapa program studi pada jenjang magister (S-2) di antaranya Program Magister Pendidikan IPS, Program Magister Manajemen, dan Program Magister Pendidikan Bahasa Inggris.

Banyaknya pilihan program studi yang ditawarkan di Universitas Kanjuruhan Malang, membuat banyak pula pengambilan keputusan bagi para peserta didik dalam memilih program studi. Salah satu program studi yang ada di Universitas Kanjuruhan Malang yaitu Program Studi Pendidikan Ekonomi. Program studi Pendidikan Ekonomi salah satu program studi yang ada di Fakultas Ekonomika dan Bisnis. Badan Nasional Akreditasi Perguruan Tinggi berdasarkan keputusan BAN-PT No 1023/SK/BAN-PT/Akred/S/VI/2017, Program Studi Pendidikan Ekonomi memperoleh akreditasi B. Sehingga lulusan dari SMA/MA, SMK setelah lulus bisa memilih Program Studi Pendidikan Ekonomi Universitas Kanjuruhan Malang.

Dalam pemilihan program studi banyak faktor-faktor yang mempengaruhi. Beberapa faktor yang mempengaruhi yaitu, kualitas pelayanan, biaya pendidikan maupun dari kelompok referensi yang timbul mempengaruhi para lulusan SMA/MA, SMK dalam memilih program studi yang mana akan dipilih dalam melanjutkan pendidikan di perguruan tinggi. Faktor tersebut memberikan pengaruh dalam meningkatkan maupun menurunkan terkait pengambilan keputusan para lulusan SMA/MA, SMK dalam memilih Program Studi Pendidikan Ekonomi.

Program Studi Pendidikan Ekonomi mempunyai peminat yang paling sedikit. Tentu hal ini menjadi pemicu oleh pihak Kaprodi untuk selalu meningkatkan kualitas Program Studi Pendidikan Ekonomi yang diberikan oleh seluruh jajaran yang ada di program Studi Pendidikan Ekonomi kepada mahasiswa. Keputusan dalam memilih program studi pada suatu Universitas merupakan tantangan besar diantara sebagian besar mahasiswa. Mereka akan mempertimbangkan dengan kondisi atau keadaan yang ada. Jika keadaan atau kondisi yang nyata tidak sesuai dengan apa yang diharapkan, maka akan terjadi keraguan yang berakibat pada keputusan untuk tidak memilih prodi yang diharapkan. Meskipun didalam pengambilan keputusan untuk menempuh pendidikan diperlukan suatu pertimbangan, akan tetapi mahasiswa Pendidikan Ekonomi belum melakukan analisis mengenai program studi yang diambilnya, padahal dampak dari penetapan tersebut akan membawa pengaruh jangka pendek bahkan jangka panjang yang diantaranya berupa keuntungan 
maupun resiko. Terlebih lagi pilihan penetapan prodi tersebut merupakan hal penting didalam menentukan rencana karir di masa depan. Pengambilan keputusan (decision making) menurut Desmita (2010) merupakan salah satu bentuk perbuatan berfikir dan hasil dari perbuatan itu disebut keputusan. Hal ini berarti bahwa dengan melihat bagaimana seseorang remaja mengambil suatu keputusan, maka dapat diketahui perkembangan pemikirannya. Sedangkan menurut Salusu dalam Rodiyah (2013:73) pengambilan keputusan adalah proses memilih suatu alternatif cara bertindak dengan metode yang efisien sesuai situasi.

Mahasiswa Prodi Pendidikan Ekonomi adalah mereka yang berasal dari latar belakang yang berbeda-beda baik itu status sosial, budaya, ras, suku dan budaya Sehingga faktor-faktor yang mempengaruhi mereka ketika memilih program studi juga berbeda dan tergantung dari setiap individu. Penelitian yang dilakukan oleh Andriani Kusumawati (2013) menunjukkan bahwa faktor biaya pendidikan, reputasi, kedekatan, prospek kerja dan orang tua merupakan faktor penting yang mempengaruhi pilihan mahasiswa memilih universitas. Mahasiswa merupakan konsumen dari produk jasa yang disediakan oleh program Studi. Analisis pengambilan keputusan selain bermanfaat bagi mahasiswa, juga bermanfaat bagi lembaga yang terkait. Keputusan mahasiswa dalam memilih program studi menjadi penting bagi Prodi Pendidikan Ekonomi sebagai sumber informasi. Informasi ini dapat membantu pihak kaprodi dalam mengembangkan komunikasi yang lebih tepat dalam hal ini adalah pemasaran dimana pemasaran adalah sistem keseluruhan dari kegiatan usaha yang di tunjukan untuk merencanakan, menentukan harga mempromosikan dan meyediakan jasa yang dapat memenuhi kebutuahan pelanggan (mahasiswa).

Menurut Tjiptono (2011:59) kualitas pelayanan adalah tingkat keunggulan yang di harapkan dan pengendalian atas tingkat keunggulan tersebut untuk memenuhi keinginan pelanggan. Sedangkan menurut Lewis ban Booms (dalam, Tjitono 2012:157) menyatakan ukuran seberapa bagus tingkat pelayanan yang berikan mampu sesuai dengan ekspetasi pelanggan. Maka dapat di simpulkan bahwa jika kenyataan lebih dari yang diharapakan maka pelayanan dapat di katakan memenuhi harapan dan sesuai dengan ekspetasi pelanggan. Biaya pendidikan merupakan salah satu komponen instrumental yang sangat penting didalam penyelenggaraan pendidikan. Tanpa dukungan biaya pendidikan yang memadai, maka proses pendidikan tidak akan berjalan dengan baik. Oleh sebab itu, sebuah lembaga pendidikan harus dapat mengelola dana untuk kelangsungan proses kegiatan belajar mengajar, tetapi tanpa membebankan semua biaya pendidikan kepada mahasiswa agar mahasiswa yang ekonominya terbatas dapat tetap menempuh pendidikan di perguruan tinggi. Menurut Supriadi (2010:3) Biaya Pendidikan menjadi salah satu masukkan instrumental (instrumental input) yang sangat penting dalam penyelenggaraan pendidikan. Menurut Mulyono (2010:82) biaya adalah jumlah uang yang disediakan atau dialokasikan dan digunakan atau dibelanjakan untuk terlaksananya berbagai fungsi atau kegiatan guna mencapai suatu tujuan dan sasaran-sasaran dalam rangka proses managemen. Berdasarkan uraian tersebut Peneliti menyimpulkan bahwa faktor biaya pendidikan mempunyai pengaruh didalam pengambilan keputusan pilihan Program Studi pada mahasiswa Prodi Pendidikan Ekonomi.

Kelompok referensi sering dijadikan pedoman oleh seseorang dalam bertingkah laku. Anggota-anggota kelompok referensi sangat berperan dalam proses sosialiasi mahasiswa sebagai konsumen. Dalam interaksinya, mahasiswa sebagai anggota dari suatu kelompok referensi secara tidak langsung akan dipengaruhi oleh norma-norma dan nilai-nilai budaya dalam masyarakat lingkungan sekitar. Meskipun kelompok referensi berhubungan erat dengan mahasiswa, akan tetapi terkadang terdapat kendala di dalam proses komunikasi sehingga terjadi ketidaksesuaian antara informasi yang disampaikan oleh kelompok referensi terhadap mahasiswa. Menurut Suryani (2013:167) kelompok referensi merupakan seorang individu atau sekelompok orang secara nyata mempengaruhi perilaku seseorang. Lebih jauh salah satu bentuk pengaruh kelompok referensi adalah pengaruh normative. Sedangkan Menurut Ujang Suwarman (2014:305) kelompok referensi/ 
acuan (reference group) adalah seorang individu atau sekelompok orang yang mempengaruhi perilaku seseorang. Maka dapat disimpulkan bahwa kelompok referensi adalah pengaruh yang diberikan oleh individu atau kelompok terhadap individu atau kelompok lain, baik pengaruh secara langsung maupun tidak langsung yang memberikan suatu standar tertentu.

\section{TINJAUAN PUSTAKA}

Pada penelitian ini, menggunakan beberapa penelitian terdahulu yang pernah dilakukan dan dapat menjadi tinjauan studi, yaitu sebagai berikut:

1. Karina Praditya Putri (2011) penelitian dengan judul "Analisis Pengaruh Brand Image, Biaya Pendidikan, dan Fasilitas Pendidikan terhadap Keputusan Mahasiswa Melanjutkan Studi pada Program Diploma III Fakultas Ekonomi Universitas Diponegoro Semarang".

2. Murdiana Utami Dianitami (2012) penelitian dengan judul "Pengaruh Kualitas Pelayanan, Biaya, Lokasi Dan Pencitraan Terhadap Keputusan Mahasiswa memilih Fakultas Ekonomi Universitas Gunadarma Kalimalang Bekasi"

3. Wan Suryani Paham Ginting (2013) penelitian dengan judul "Faktor-faktor yang mempengaruhi keputusan Mahasiswa memilih fakultas ekonomi Universitas islam sumatera utara Al munawaroh medan"

4. Andriani Kusumawati (2013) penelitian dengan judul Journal of Basic and Applied Scientific Research yang berjudul "A Qualitative Study of the Factors Influencing Student Choice: The Case of Public University in Indonesia".

Menurut Desmita (2010) merupakan salah satu bentuk perbuatan berfikir dan hasil dari perbuatan itu disebut keputusan. Menurut Tjiptono (2011:59) kualitas pelayanan adalah tingkat keunggulan yang di harapkan dan pengendalian atas tingkat keunggulan tersebut untuk memenuhi keinginan pelanggan. Menurut Supriadi (2010:3) Biaya Pendidikan menjadi salah satu masukkan instrumental (instrumental input) yang sangat penting dalam penyelenggaraan pendidikan. Menurut Ujang Suwarman (2014:305), kelompok referensi/ acuan (reference group) adalah seorang individu atau sekelompok orang yang mempengaruhi perilaku seseorang.

\section{METODE}

Berdasarkan tujuan yang ingin dicapai dalam penelitian ini untuk mengetahui pengaruh antara variabel bebas (kualitas pelayanan, biaya pendidikan dan kelompok referensi) terhadap variabel terikat (keputusan mahasiswa). Maka rancangan penelitian yang digunakan adalah penelitian Kuantitatif dengan empat variabel. Penelitian eksperimen merupakan metode penelitian yang digunakan untuk mencari pengaruh perlakuan tertentu terhadap yang lain dalam kondisi yang terkendalikan. Untuk memperoleh gambaran secara empiris serta mencari pemecahan masalah. Peneliti berencana menyebarkan angket untuk memperoleh gambaran sejauh mana adanya pengaruh Kualitas Pelayanan, Biaya Pendidikan. dan Kelompok Referensi Terhadap Keputusan Mahasiswa Memilih Program Studi Pendidikan Ekonomi di Universitas Kanjuruhan Malang.

Menurut Sugiyono (2010:90) populasi adalah "wilayah generalisasi yang terdiri atas obyek atau subyek yang mempunyai kualitas dan karakteristik tertentu yang ditetapkan oleh peneliti untuk dipelajari dan kemudian ditarik kesimpulannya". Sesuai dengan pengertian tersebut maka populasi yang dimaksud disini adalah seluruh mahasiswa pendidikan ekonomi angkatan 2015 sampai 2018. Jumlah populasi sebesar 122 mahasiswa. Menurut Sugiyono (2010:91), sampel adalah bagian dari jumlah dan karakteristik yang dimiliki oleh populasi. Dalam pengambilan sampel harus representatif, yang artinya harus dapat menggambarkan keadaan populasi yang seharusnya. Teknik pengambilan sampel pada penelitian ini dilakukan dengan mengunakan teknik Proporsional random sampling, yaitu teknik pengambilan sampel dengan acak tanpa melihat strata. (Sugiyono, 2012:124). 
Menurut (Sugiyono 2011:81). Sampel adalah bagian dari jumlah dan karakteristik yang dimiliki oleh populasi tersebut. Bila populasi besar, dan peneliti tidak mungkin mempelajari semua yang ada pada populasi, misalnya karena keterbatasan dana, tenaga dan waktu, maka peneliti dapat menggunakan sampel yang diambil. Teknik pengumpulan data merupakan cara yang digunakan dalam pengumpulan data penelitian, untuk memperoleh data yang diperlukan dalam penelitian ini, peneliti menggunakan dua teknik pengumpulan data yaitu kuesioner (angket) dan dokumentasi

\section{PEMBAHASAN}

Penelitian ini mengambil tiga variabel bebas yang diduga memiliki pengaruh terhadap keputusan mahasiswa memilih program studi pendidikan ekonomi di universitas kanjuruhan malang. Deskripsi hasil penelitian ini didapat dari pengumpulan data dengan menggunakan instrumen penelitian skala likert. Pemaparan tersebut meliputi beberapa variabel diantaranya yaitu kualitas pelayanan (XI), biaya pendidikan (X2), dan kelompok referensi (X3) yang mencakup mean, median, standart deviation, skor minimum, dan skor maksimum.

Berdasarkan hasil perhitungan statistik dengan bantuan computer melalui program SPSS Versi 22.0 for windows diperoleh tabel Anova yang menunjukkan uji F statistik. Adapun hasil dari uji F pada Tabel Anova adalah sebagai berikut:

\section{Tabel 1 Hasil Uji F (Uji Secara Simultan)}

ANOVAa

\begin{tabular}{|c|c|c|c|c|c|c|}
\hline \multicolumn{2}{|l|}{ Model } & \begin{tabular}{|l|} 
Sum of \\
Squares
\end{tabular} & Df & Mean Square & $\mathrm{F}$ & Sig. \\
\hline 1 & Regression & 67.791 & 3 & $\begin{array}{r}22.597 \\
\end{array}$ & 14.623 & $.000^{\mathrm{b}}$ \\
\hline & Residual & 89.628 & 58 & 1.545 & & \\
\hline & Total & 157.419 & 61 & & & \\
\hline
\end{tabular}

a. Dependent Variable: Keputusan Mahasiswa

b. Predictors: (Constant), Kualitas Pelayanan, Biaya Pendidikan, Kelompok Referensi

Sumber: SPSS Versi 22.0 for windows

Berdasarkan tabel 1 pengambilan keputusan untuk pengujian hipotesis yang diajukan adalah sebagai berikut: hasil anova di peroleh nilai $\mathrm{F}$ sebesar 14,623 dengan tingkat signifikan 0,000 a karena tingkat signifikan lebih kecil dari 0,05 , maka $\mathrm{H}_{1}$ ditolak dan $\mathrm{H}_{2}$ di terima, artinya yaitu: kualitas pelayanan $\left(\mathrm{X}_{1}\right)$, biaya pendidikan $\left(\mathrm{X}_{2}\right)$ dan kelompok referensi $\left(\mathrm{X}_{3}\right)$ secara bersma-sama (simultan) berpengaruh secara signifikan terhadap keputusan mahasiswa $(\mathrm{Y})$.

Berdasarkan hasil perhitungan statistik dengan bantuan computer melalui program SPSS Versi 22.0 for windows diperoleh tabel coefficients yang menunjukkan uji t statistik. Uji t digunakan untuk menguji signifikan pengaruh masing-masing dari variabel independen yang terdiri dari pengetahuan tentang koperasi, kualitas layanan, dan motivasi berkoperasi dengan variabel dependen yaitu partisipasi anggota. Hasil uji t pada penelitian ini dapat dilihat pada Tabel 2 berikut ini yaitu:

Tabel 2 Hasil Uji t (Uji Signifikan Parsial)

\begin{tabular}{|c|c|c|c|c|}
\hline \multicolumn{4}{|c|}{ Coefficients $^{a}$} & \multirow[b]{2}{*}{ Keterangan } \\
\hline & Model & $\mathrm{T}$ & $\begin{array}{l}\text { Sig } \\
.\end{array}$ & \\
\hline \multirow[t]{4}{*}{1} & (Constant) & 10,694 & .000 & \\
\hline & Kualitas Pelayanan & 6,039 & .000 & Signifikan \\
\hline & Biaya Pendidikan & $-2,093$ & .041 & Signifikan \\
\hline & Kelompok Referensi & 2,172 & .034 & Signifikan \\
\hline
\end{tabular}

Sumber: SPSS Versi 22.0 for windows 
Berdasarkan tabel 2 hipotesis penelitian untuk memuji hipotesis kedua $\left(\mathrm{H}_{2}\right)$ adalah sebagai berikut: berdasarkan hasil analisis diperoleh nilai $t$ hitung $=6.031$ dengan nilai sig 0,000 lebih kecil yang artinya kualitas pelayanan $\left(\mathrm{X}_{1}\right)$ memiliki pengaruh yang signifikan terhadap keputusan mahasiswa (Y). Hipotesis penelitian untuk menguji hipotesis ketiga $\left(\mathrm{H}_{3}\right)$ adalah sebagai sebagai berikut: berdasarkan hasil analisis diperoleh nilai $\mathrm{t}$ hitung $=-2.093$ dengan nilai sig 0,41 lebih kecil yang artinya biaya pendidikan $\left(\mathrm{X}_{3}\right)$ memiliki pengaruh yang signifikan terhadap keputusan mahasiswa (Y). Hipotesis penelitian untuk menguji hipotesis keempat $\left(\mathrm{H}_{4}\right)$ adalah sebagai sebagai berikut: berdasarkan hasil analisis diperoleh nilai $\mathrm{t}$ hitung $=2.172$ dengan nilai sig 0.034 lebih kecil yang artinya kelompok referensi $\left(\mathrm{X}_{4}\right)$ memiliki pengaruh yang signifikan terhadap keputusan mahasiswa $(\mathrm{Y})$.

\section{KESIMPULAN}

Berdasarkan hasil analisis data yang telah dilakukan oleh peneliti dengan responden mahasiswa pendidikan ekonomi, maka dapat diambil kesimpulan sebagai berikut, yaitu bahwa kualitas pelayanan, biaya pendidikan, dan kelompok referensi secara bersama-sama (simultan) berpengaruh positif dan signifikan terhadap keputusan mahasiswa memilih program studi pendidikan di universitas kanjuruhan malang. Sedangkan untuk hasil analisis secara sendiri-sendiri (parsial) diperoleh hasil bahwa kualitas pelayanan secara parsial terdapat pengaruh positif dan signifikan terhadap keputusan mahasiswa memilih program studi pendidikan ekonomi. Pada variabel biaya pendidikan secara parsial terdapat pengaruh yang positif dan signifikan terhadap keputusan mahasiswa memilih program studi pendidikan ekonomi. Kelompok referensu secara parsial berpengaruh negatif tetapi signifikan terhadap keputusan mahasiswa memilih program studi pendidikan ekonomi.

\section{DAFTAR PUSTAKA}

Andriani Kusumawati. (2013). A Qualitative Study of the Factors Influencing Student Choice: The Case of Public University in Indonesia. Jurnal.Universitas Brawijaya Malang.

Desmita. (2010). Psikologi Pembangunan. Bandung : PT Remaja Rosdakarya

Fandy Tjiptono.(2011). Pemasaran Jasa. Yogyakarta: Bayumedia Publishing

J. Salusu. (2013). Pengambilan Keputusan Strategik Untuk Organisasi Publik dan Organisasi Non Profit.

Grasindo. Jakarta.

Karina Pradityas Putri. (2011). Analisis Pengaruh Brand Image, Biaya Pendidikan, dan Fasilitas Pendidikan terhadap Keputusan Mahasiswa Melanjutkan Studi pada Program Diploma III Fakultas Ekonomi Universitas Diponegoro Semarang. Skripsi. Universitas Diponegoro.

Mulyono. (2010). Konsep Pembiayaan Pendidikan. Yogjakarta : Ar Ruzz Media Mehboob, Farhan, et al. 2012. Factors Influencing Students Enrollment Decisions in Selection of Higher Education Institutions (HEI,,S). Insitute of Interdisciplinary Business Research. Vol. 4, No. 5.

Murdiana Dianitami Utami. (2012). Pengaruh Kualitas Pelayanan, Biaya, Lokasi Dan Pencitraan Terhadap Keputusan Mahasiswamemilih Fakultas Ekonomi Universitas Gunadarma Kalimalang Bekasi. Journal. Universitas Gunadarma.

Sugiyono. (2010). Memahami Penelitian Kualitatif. Bandung: Alfabeta.

Sugiyono. (2011). Metode Penelitian Kuantitatif, Kualitatif dan RED. Bandung: Alfabeta.

Supriadi, Dede. (2010). Satuan Biaya Pendidikan Dasar dan Menengah. Bandung : PT Remaja

Rosdakarya.

Suryani, Tatik. (2013). Perilaku Konsumen di Era Internet. Yogyakarta: Graha Ilmu.

Tjiptono, Fandy dan Gregorius Chandra. (2012). Pemasaran Strategik. Yogyakarta:ANDI

Ujang Sumarwan. (2011). Perilaku Konsumen. PT Ghalia Indonesia, Jakarta. 
Wan Suryani Paham Ginting. (2013). Faktor-faktor yang mempengaruhi keputusan Mahasiswa memilih fakultas ekonomi Universitas islam sumatera utara $\mathrm{Al}$ munawaroh medan. Journal. Universitas Islam Sumatera Utara 